\title{
Comparison of ranitidine and cimetidine in the inhibition of histamine, sham-feeding, and meal- induced gastric secretion in duodenal ulcer patients
}

\author{
S J KONTUREK,* W OBTULOWICZ, N KWIECIEN, E SITO \\ E MIKOS, AND J OLEKSY
}

From the Institute of Physiology, Medical Academy, Krakow, and District Hospital, Krakow, Poland

SUMmARY The effects of ranitidine, a new $\mathrm{H}_{2}$-receptor antagonist which does not contain an imidazole ring, and cimetidine have been determined on histamine, meal-induced gastric acid secretion, and serum gastrin levels in duodenal ulcer patients. Compared with cimetidine, ranitidine was found to be about eight times more potent an inhibitor of histamine-induced secretion and four to five times more potent an inhibitor of sham-feeding, and real feeding induced acid secretion without effecting serum gastrin levels.

The discovery by Black and his associates ${ }^{1}$ of a new class of drugs that specifically block the action of histamine on gastric acid secretion has revolutionised the treatment of peptic ulcer and other acid-pepsin diseases. The beneficial effects of these so-called $\mathrm{H}_{2}$-receptor antagonists on ulcer healing and symptom relief result from their potent inhibitory action on gastric acid secretion induced not only by histamine but also by a variety of other stimulants including gastrin, acetylcholine, stable cholinergic esters, caffeine, insulin, gastric distention, shamfeeding, and real feeding. ${ }^{23}$

At present, cimetidine (Tagamet) is the only widely accepted representative of this type of agent which blocks $\mathrm{H}_{2}$-receptors, an action thought to be due to the imidazole ring present in its structure. ${ }^{4}$ Recently, a new compound, ranitidine, has been shown to block $\mathrm{H}_{2}$-receptors in the stomach of laboratory animals ${ }^{5}$ and in man. ${ }^{6} 7$ but this compound does not have an imidazole ring. Thus a study was undertaken to compare the effectiveness of ranitidine and cimetidine in inhibiting histamine and sham-feeding or meal-induced gastric secretion in duodenal ulcer patients.

\section{Methods}

The study group consisted of 12 patients with wellestablished chronic duodenal ulcer (DU) disease and a mean age of 22 years (range 20-25 years) and mean

*Address for correspondence: Professor Dr S J Konturek, Institute of Physiology, 31-531 Krakow, ul. Grzegorzecka 16, Poland.

Received for publication 22 October 1979 weight of $68 \mathrm{~kg}$ (range $62-72 \mathrm{~kg}$ ). All these patients were in clinical remission when their study period began. The study was approved by the Human Research Review Committee and informed consent was obtained from each subject. The patients received no anticholinergics or any other antisecretory drug for at least five days before the secretory studies were started.

\section{SECRETORY PROCEDURE}

In all tests, except those with gastrointestinal phase, a double lumen Dreiling tube was inserted and a few hours later positioned under fluoroscopic control with the tip at the junction of the third and fourth parts of the duodenum. A paediatric endotracheal tube cuff mounted over the Dreiling tube was placed midway between the gastric and duodenal orifices. At the beginning of each study the cuff was inflated with $20 \mathrm{ml}$ of air to prevent the reflux of duodenal content into the stomach or the escape of gastric juice into the duodenum as described previously. ${ }^{8}$

The volume of gastric aspirates was recorded and the acidity of gastric juice was measured by titrating $0.2 \mathrm{ml}$ samples with $0.1 \mathrm{~N} \mathrm{NaOH}$, using an automatic titrator (Autoburet, Radiometer, Copenhagen, Denmark). Acid outputs were expressed in millimoles (mmol) per 15 or 30 minutes. The pepsin concentration in the gastric juice was determined using a modification of the Anson ${ }^{9}$ haemoglobin method and expressed as $\mathrm{mg}$ pepsin per $\mathrm{ml}$ by reading the absorbance of the trichloracetic acid supernatant at $280 \mathrm{~nm}$ and comparing with standards 
incubated with different concentrations of pepsin solutions (Pentex Biochemical, Kankakee, Illinois). Pepsin outputs were calculated, taking into consideration the dilution of samples and expressed as mg pepsin per 15 or 30 minutes.

\section{EXPERIMENTAL DESIGN}

Patients were divided into two groups-a group of four subjects was used for histamine studies, and a group of eight subjects for studies on cephalic and gastrointestinal phases of gastric secretion. Throughout each study an infusion of $154 \mathrm{mM} \mathrm{NaCl}$ was delivered in an arm vein at $80 \mathrm{ml} / \mathrm{h}$ by peristaltic pump. Two 15 minute collections of gastric juice were first obtained to determine basal gastric secretion.

In tests with histamine, promethazine was injected intramuscularly in a dose of $15 \mathrm{mg}$ at the beginning of the tests and then, after basal collections, histamine dihydrochloride was infused in a constant dose $(40 \mu \mathrm{g} / \mathrm{kg}-\mathrm{h})$ throughout the examination. After 60 minutes of histamine infusion, when the secretory rate reached a peak, ranitidine or cimetidine was added to the intravenous infusion starting with a dose of 0.06 and $0.5 \mathrm{mg} / \mathrm{kg}-\mathrm{h}$, respectively. The dose of the $\mathrm{H}_{2}$-blocker was then doubled every 60 minute period. The dose of ranitidine ranged from 0.06 to $0.5 \mathrm{mg} / \mathrm{kg}-\mathrm{h}$, and that of cimetidine from 0.5 to $4.0 \mathrm{mg} / \mathrm{kg}-\mathrm{h}$. In control tests, histamine alone was administered throughout the examination.

In tests with cephalic phase of gastric secretion, the subjects chewed but did not swallow an appetising meal consisting of $250 \mathrm{~g}$ beef steak, $140 \mathrm{~g}$ french fried potatoes, and $250 \mathrm{ml}$ water. All meals were prepared in a separate building so that the subjects could not see or smell the food until the time of the sham-feeding and each subject was trained in a preliminary study not to swallow food. This shamfeeding procedure took 30 minutes. During all tests gastric aspirates were carefully checked for swallowed food particles and none was found. In addition, phenol red was added to the $250 \mathrm{ml}$ of water used in the sham feeding and gastric samples were analysed for phenol red and again none was found. Phenol red concentration in each sample was measured spectrophotometrically at $575 \mathrm{~nm}$ after being alkalinised to $\mathrm{pH} 11 \cdot 5$. The infusion of ranitidine or cimetidine was started 45 minutes before the beginning of sham-feeding and continued during and after this procedure. Ranitidine was given in a dose of $0.5 \mathrm{mg} / \mathrm{kg}-\mathrm{h}$ and cimetidine in a dose of 2.0 $\mathrm{mg} / \mathrm{kg}-\mathrm{h}$.

In the tests with gastrointestinal phase of gastric secretion a modification of the intragastric titration technique $^{8}$ was applied.
The test meal used for intragastric titration consisted of a $5 \%$ aqueous solution of a liver concentrate powder (Reheis Chemical Co, Chicago, Ill.), and allowed to flow continuously into the stomach from a reservoir barostat. Acid outputs were measured by intragastric titration with the end point of pH 5.5. Ranitidine or cimetidine was added to intravenous infusion after a 45 minute period of the titration, when acid output reached a well-sustained plateau, and continued for a 60 minute period. The doses of these $\mathbf{H}_{2}$-blockers were the same as in tests with sham-feeding. For the comparison of the secretory responses to cephalic or gastrointestinal phase, each subject was tested with pentagastrin (Peptavlon, Ayerts Lab., New York) given in a constant dose of $2 \mu \mathrm{g} / \mathrm{kg}-\mathrm{h}$ for a 90 minute period to achieve the maximal acid output.

\section{SERUM GASTRIN}

In all tests except those with histamine and pentagastrin, venous blood samples were obtained from a peripheral vein for measurement of serum gastrin level. In tests with cephalic phase, blood samples were taken at 15 and 30 minutes before the start of $\mathrm{H}_{2}$-blocker infusion, 15 minutes before the beginning of sham-feeding and then at $15,30,45,60,90$, and 120 minutes after this procedure. In tests with gastrointestinal phase, blood samples were withdrawn 15 and 30 minutes before and every 30 minute period during the test meal. Serum gastrin was measured by radioimmunoassay technique. ${ }^{10}$ Antibody to gastrin rabbit antiserum 4562 was used at a final dilution $1: 100000$. With this antibody human heptadecapeptide gastrins (G-17I and G-17II) and human big gastrins (G-34I and G-34II) were measured on nearly equimolar basis, G-34 being approximately two-thirds as immunoreactive as G-17.

All determinations were made in duplicate. The within-assay variation was $9 \%$ and interassay variation was $14 \%$. The immunoassay system was sufficiently sensitive to detect $5 \mathrm{pg} / \mathrm{ml}$ of serum gastrin.

STATISTICAL EVALUATION OF RESULTS

Results are expressed as the mean \pm SEM. Student's test was used to determine the significance of difference between the means, with differences giving a $P$ value of less than 0.05 being considered significant. ${ }^{11}$

\section{Results}

EFFECTS OF RANITIDINE AND CIMETIDINE ON HISTAMINE-INDUCED GASTRIC SECRETION The effect of graded doses of ranitidine or cimetidine infused against a constant background dose of 


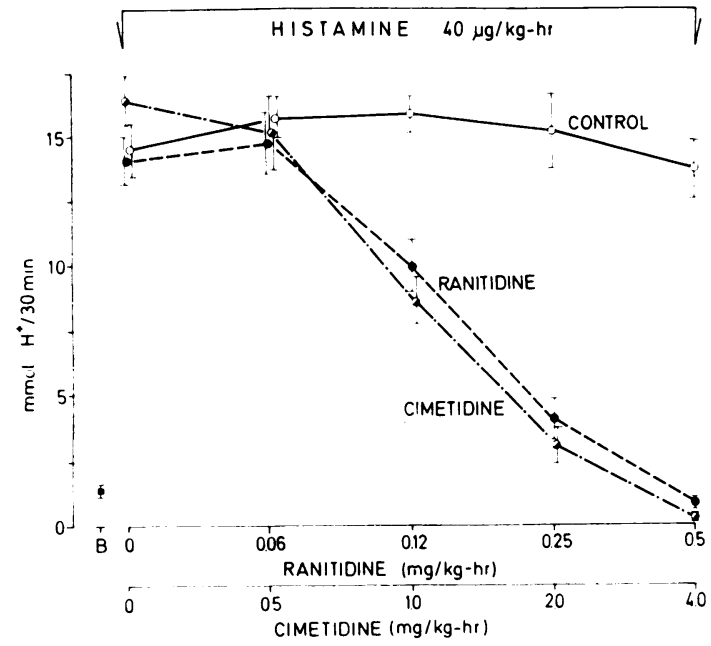

Fig. 1 Effect of graded doses of ranitidine and cimetidine on histamine-induced gastric acid secretion in duodenal ulcer patients. Mean $\pm S E M$ of four tests in four duodenal ulcer patients.

histamine $(40 \mu \mathrm{g} / \mathrm{kg}-\mathrm{h})$ producing the highest observed acid response (maximal) is presented in Fig. 1. Increasing the dose of $\mathbf{H}_{2}$-blocker resulted in a corresponding increase in the inhibition of gastric acid secretion. The dose required for $50 \%$ inhibition of maximal response to histamine equalled about $0.15 \mathrm{mg} / \mathrm{kg}$-h ranitidine and $1.3 \mathrm{mg} / \mathrm{kg}$-h cimetidine. Thus, the inhibitory potency of ranitidine was about eight times greater than that of cimetidine. The administration of $0.5 \mathrm{mg} / \mathrm{kg}-\mathrm{h}$ ranitidine or 4.0 $\mathrm{mg} / \mathrm{kg}$-h cimetidine caused almost complete inhibition of acid response to histamine.

Pepsin outputs in tests with histamine plus $\mathrm{H}_{2}$ blocker paralleled acid outputs (Fig. 2). With in-

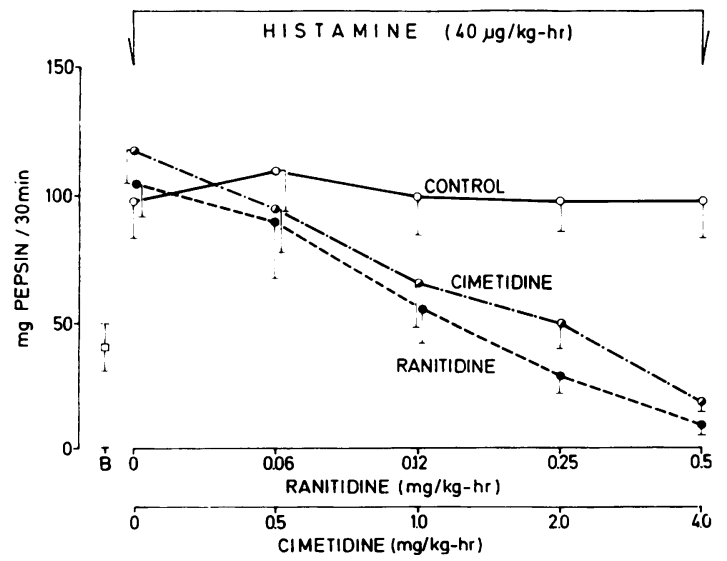

Fig. 2 Pepsin outputs in tests as in Fig. 1.

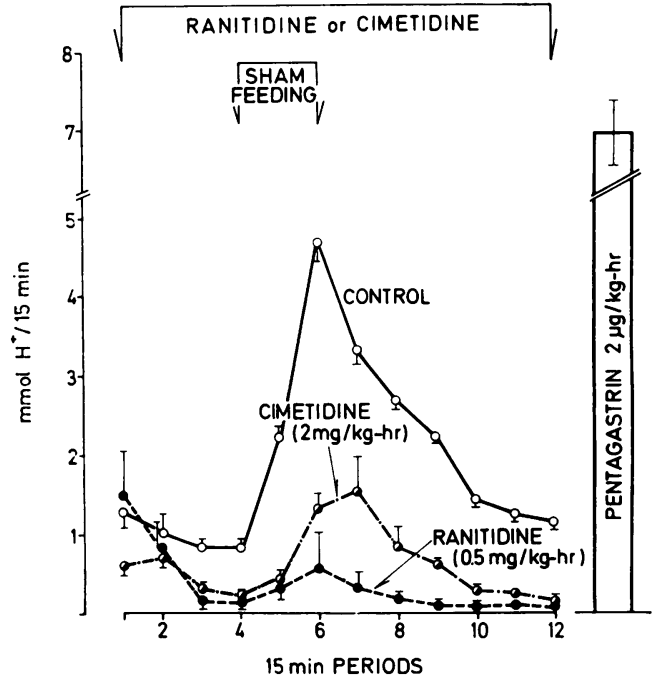

Fig. 3 Effect of ranitidine and cimetidine on sham-feeding induced gastric acid secretion in duodenal ulcer patients. Mean $\pm S E M$ of eight tests in eight duodenal ulcer patients. Vertical bar represents maximal acid response to pentagastrin in these patients.

creasing doses of $\mathrm{H}_{2}$-blocker the pepsin output fell dose-dependently and this decrease was almost entirely due to a reduction in the volume flow of gastric juice without significant change in pepsin concentration.

\section{EFFECTS OF RANITIDINE OR CIMETIDINE} ON CEPHALIC PHASE OF GASTRIC SECRETION AND SERUM GASTRIN LEVEL

In control tests with sham-feeding, the mean peak of acid output was equivalent to about $66 \%$ of maximum pentagastrin stimulated acid output. Ranitidine in a dose of $0.5 \mathrm{mg} / \mathrm{kg}$-h strongly reduced basal acid output and almost completely prevented the increase in acid secretion in response to shamfeeding. Cimetidine in a dose of $2 \mathrm{mg} / \mathrm{kg}$-h also reduced basal acid output and decreased by about $70 \%$ the response to sham-feeding (Fig. 3). An increase in acid secretion in response to sham-feeding was accompanied by a rise in pepsin secretion due to an increase in both volume flow and pepsin concentration of gastric juice; ranitidine almost completely abolished pepsin response to sham-feeding, whereas cimetidine reduced this response to about $50 \%$ of control value (Fig. 4).

Serum gastrin responses to sham-feeding with and without $\mathbf{H}_{2}$-blocker are presented in the Table. No significant changes in serum gastrin levels were observed during or after sham-feeding and neither ranitidine nor cimetidine significantly affected these levels. 


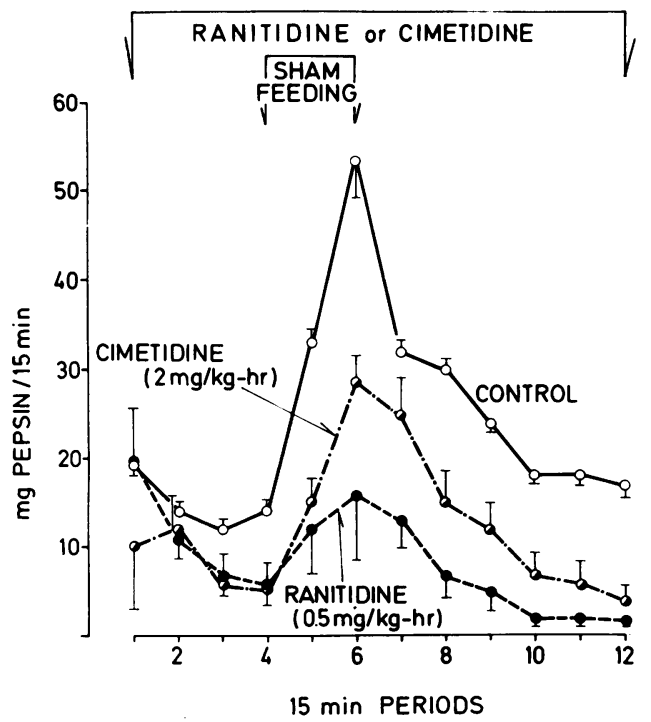

Fig. 4 Pepsin outputs in tests as in Fig. 3.

EFFECT OF RANITIDINE AND CIMETIDINE ON GASTROINTESTINAL PHASE OF GASTRIC ACID SECRETION AND SERUM GASTRIN LEVELS (Fig. 5)

Gastric acid response to a liver extract (LE) meal introduced into the stomach to evoke the gastrointestinal phase of secretion was as high as that to pentagastrin and remained relatively well sustained throughout the control experiment. This was accompanied by an increase in serum gastrin level from a basal value of about 20 to $45 \mathrm{fmol} / \mathrm{ml}$. Ranitidine given in a dose of $0.5 \mathrm{mg} / \mathrm{kg}-\mathrm{h}$ resulted in an immediate and almost complete inhibition of the acid response, which remained suppressed even after the discontinuation of ranitidine infusion.

Cimetidine ( $2 \mathrm{mg} / \mathrm{kg}-\mathrm{h})$ also dramatically inhibited postprandial acid secretion, which fell to about $75 \%$ of control value at the end of the cime-

Table Serum gastrin concentrations before and after sham-feeding in eight duodenal ulcer patients receiving saline (control), ranitidine $(0.5 \mathrm{mg} / \mathrm{kg}-\mathrm{h})$, or Tagamet (2 $\mathrm{mg} / \mathrm{kg}-\mathrm{h}$ )

\begin{tabular}{lrrrrrrrr}
\hline \multirow{2}{*}{ Type of test } & \multicolumn{9}{l}{ Serum gastrin $(\mathrm{pg} / \mathrm{ml})$} \\
\cline { 2 - 8 } & \multicolumn{1}{l}{ Time $(\mathrm{min})$} \\
\cline { 2 - 8 } & -30 & -15 & $+15^{*}$ & $+30^{*}$ & +45 & +60 & +90 & +120 \\
\hline Control & 47 & 41 & 45 & 43 & 48 & 50 & 63 & 62 \\
& \pm 8 & \pm 7 & \pm 8 & +8 & \pm 5 & \pm 8 & \pm 8 & \pm 10 \\
Ranitidine & 46 & 45 & 50 & 58 & 70 & 72 & 62 & 63 \\
Tagamet & +7 & +9 & +8 & +12 & +12 & +9 & +8 & +6 \\
& 49 & 45 & 51 & 59 & 62 & 64 & 61 & 62 \\
& +6 & +9 & +7 & +12 & +11 & +10 & +9 & +10 \\
\hline
\end{tabular}

- Periods of time when sham-feeding was performed.
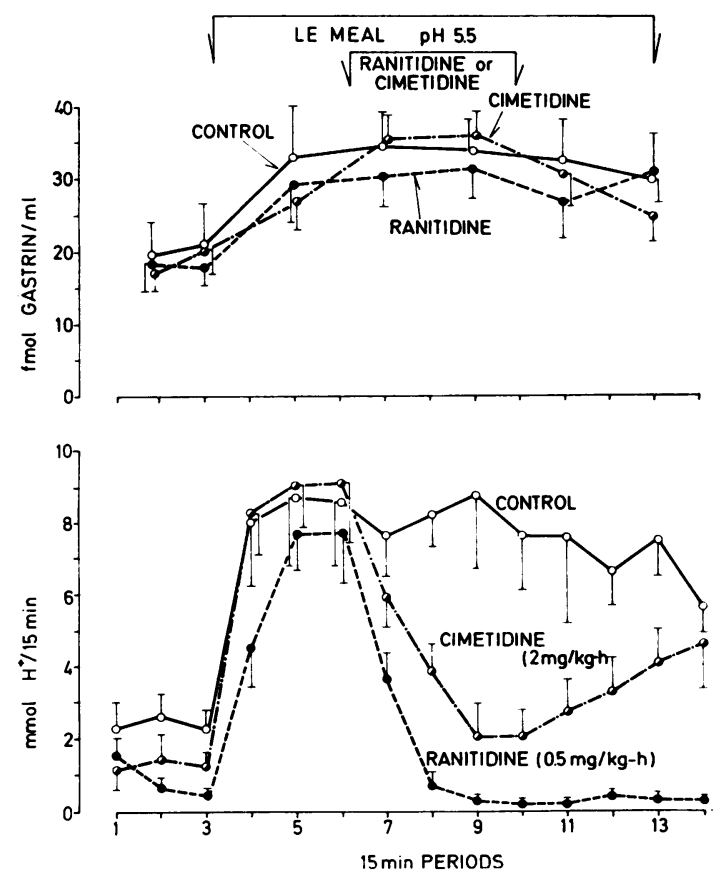

Fig. 5 Effect of ranitidine or cimetidine on meal-induced acid and serum gastrin secretion in duodenal ulcer patients.

tidine infusion but then showed a tendency to increase when the cimetidine was withdrawn. Neither ranitidine nor cimetidine influenced significantly the postprandial rise in serum gastrin level.

No symptoms or side-effects were recorded with either ranitidine or cimetidine. No changes in blood pressure, pulse rate, or body temperature were noted during or after either drug. In tests with histamine, the usual flush accompanying histamine infusion completely disappeared during the administration of ranitidine and cimetidine. This occurred at doses which did not influence gastric acid secretion $(0.06 \mathrm{mg} / \mathrm{kg}-\mathrm{h}$ ranitidine and $0.5 \mathrm{mg} / \mathrm{kg}-\mathrm{h}$ cimetidine).

\section{Discussion}

Histamine receptors involved in the stimulation of the oxyntic cells have not so far been identified by physiochemical methods and they are characterised only pharmacologically by means of specific agonists and antagonists. Starting from the structure of histamine, chemical modifications resulted in the development of specific competitive histamine $\mathbf{H}_{2}$ antagonists, such as metiamide or cimetidine, which resemble histamine by an imidazole ring and a cationic side chain. The structure-function investigations concluded that the imidazole ring is a neces- 
HISTAMINE

CIMETIDINE

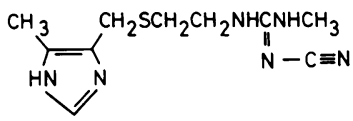

RANITIDINE

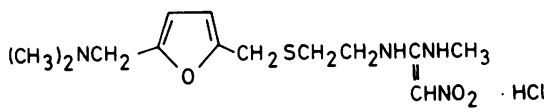

Fig. 6 Structures of histamine and two $\mathrm{H}_{2}$-blockers, ranitidine and cimetidine.

sary feature of these antagonists to recognise and to bind specifically with the $\mathrm{H}_{2}$-receptor site for a competitive antagonism. ${ }^{4}$

Unlike conventional $\mathbf{H}_{2}$-receptor antagonists such as metiamide or cimetidine, ranitidine does not contain the imidazole ring but is a substituted amino-alkyl furan (Fig. 6).

From the results presented it appears, therefore, that the presence of the imidazole ring is not essential for the $\mathrm{H}_{2}$-receptor blocking activity. Ranitidine resembles conventional $\mathrm{H}_{2}$-antagonists by the presence of isosteric thioether link in the side chain, but additional studies are required to determine which part of the molecule is important for its activity at $\mathrm{H}^{2}$-receptors.

Our comparative studies showed that ranitidine is about eight times more potent than cimetidine in inhibiting histamine-induced acid secretion and four to five times more potent in suppressing the physiological type of stimulation induced by cephalic or gastrointestinal phase of postprandial gastric secretion. The inhibition of histamine-induced secretion was dose-dependent and accompanied by a parallel fall in pepsin secretion. The finding that ranitidine was a more potent inhibitor of histamine than of meal-induced gastric secretion indicates that this $\mathrm{H}_{2}$-blocker is more specific in the suppression of histamine-induced acid secretion than of other modes of secretory stimulation.

According to the present view, histamine activates the secretory activity of the oxyntic cells via $\mathrm{H}_{2}$ receptors, whereas postprandial gastric secretion during the cephalic, gastric, and intestinal phase has dual nervous and hormonal components that are closely related and potentiate each other. Two wellrecognised direct endogenous stimulants of oxyntic cells released postprandially are acetylcholine and gastrin. ${ }^{12}$ Acetylcholine appears to be the major mediator of cholinergic activation of oxyntic cells during cephalic phase stimulation evoked in our study by sham-feeding. Our finding that serum gastrin was not affected by sham-feeding disagrees with previous reports ${ }^{1314}$ and suggests that the contribution of gastrin in the cephalic phase is rather doubtful and non-essential in duodenal ulcer patients.

Our observation that ranitidine is capable of completely abolishing the sham-feeding induced acid and pepsin secretion is strong evidence for the important role of histamine and $\mathrm{H}_{2}$-receptors in cholinergic activation of the oxyntic cells. As blockade of cholinergic receptors by atropine only partially inhibits sham-feeding induced gastric secretion in duodenal ulcer patients ${ }^{15}$ it may be concluded that $\mathrm{H}_{2}$-receptors are more important than cholinergic receptors in the activation of the oxyntic cells during the cephalic phase.

Gastric and intestinal phases of secretion are mediated by gastrin, cholinergic nerves, and other ill-defined stimulants of gastric and intestinal origin. ${ }^{12}$ The principal mechanism of this secretion is by release of gastrin, which is increased, probably due to direct excitation of the gastrin-producing cells, gastric distention, and antral neutralisation. Like the cephalic phase, the gastrointestinal phase of gastric secretion evoked by the introduction of the LE meal into the stomach was almost entirely suppressed by ranitidine without affecting serum gastrin response to this meal. This fact suggests that $\mathrm{H}_{2}$-receptors are not involved in postprandial gastrin release and is in agreement with previous reports. ${ }^{1617}$ The fact that both ranitidine and cimetidine can abolish postprandial gastric acid response indicates that histamine and $\mathrm{H}_{2}$-receptors also mediate the stimulation of the oxyntic cells during the gastrointestinal phase. The question of whether histamine is the 'final common mediator' or general sensitiser of the oxyntic cells to other stimuli involved in the postprandial secretion remains to be answered but the studies on the isolated oxyntic cells support the latter function of this biogenic amine. ${ }^{18}$

Ranitidine was recently reported to powerfully inhibit nocturnal and pentagastrin-induced secretion $^{67}$ and to be several times more potent an inhibitor than cimetidine. ${ }^{6}$ Cimetidine, which is now so widely used in peptic ulcer therapy, has been reported to cause various side-effects including gynecomastia ${ }^{19}$ increased plasma prolactin level, ${ }^{20}$ male sexual dysfunction, ${ }^{21}$ and mental confusion. ${ }^{22}$

The availability of ranitidine, a more powerful inhibitor of gastric secretion, provides an alternative to cimetidine for clinical conditions in which blockage of $\mathrm{H}_{2}$ receptors is useful.

We wish to thank Dr J L Bem of Glaxo Group Research Ltd, Ware, Hertfordshire SG12 0DJ for the gift of ranitidine. 


\section{References}

'Black JW, Duncan WAM, Durant CJ, Ganellin CR, Parsons EM. Definition and antagonism of histamine $\mathrm{H}_{2}$-receptors. Nature 1972; 236: 385-90.

${ }^{2}$ Konturek SJ, Biernat J, Oleksy J. Effect of metiamide, a histamine $\mathbf{H}_{\mathbf{2}}$-receptor antagonist on gastric response to histamine, pentagastrin, insulin and peptone meal in man. Am J Dig Dis 1974; 19: 609-16.

${ }^{3}$ Konturek SJ. Drug-induced inhibition of gastric secretion. Scand J Gastroenterol 1977; 11: Suppl 42, 101-11.

${ }^{4}$ Brimblecombe RW, Duncan WAM, Durant GJ, et al. Characterization and development of cimetidine as a histamine $\mathrm{H}_{2}$-receptor antagonist. Gastroenterology 1978; 74: 339-47.

${ }^{5}$ Bradshaw J, Brittain RT, Clitherow JW et al. Ranitidine (AH 19065); a new potent, selective histamine $\mathrm{H}_{2}$ receptor antagonist. Br J Pharmacol 1979; 66: 464 (abstract).

${ }^{6}$ Domschke W, Lux G, Domschke S. Gastric inhibitory action of $\mathbf{H}_{2}$-antagonists ranitidine and cimetidine. Lancet 1979; 1 : 320 (letter).

'Peden NR, Saunders JHB, Wormsley KG. Inhibition of pentagastrin-stimulated and nocturnal gastric secretion by ranitidine. Lancet $1979 ; 1: 690-2$.

${ }^{8}$ Konturek SJ, Biernat J., Kwiecién N, Oleksy J. Effect of glucagon on meal-induced gastric secretion in man. Gastroenterology 1975; 68: 448-54.

${ }^{9}$ Anson ML. The estimation of pepsin, trypsin, papain and cathepsin with hemoglobin. J Gen Physiol 1938; 22: 79-89.

${ }^{10}$ Yalow RS, Berson SA. Radioimmunoassay of gastrin. Gastroenterology 1970; 58: 1-14.

${ }^{1}$ Siegel S. Nonparametric statistics for the behavioral sciences. New York: McGraw-Hill, 1956.

${ }^{12} \mathrm{Grossman}$ MI. Control of gastric secretion. In: Sleis- enger MH, Fordtran JS, eds. Gastrointestinal diseases. Philadelphia: Saunders, 1978: 640-59.

${ }^{13}$ Mayer G, Arnold R, Feurle G et al. Influence of feeding and sham-feeding upon serum gastrin and gastric acid secretion in control subjects and duodenal ulcer patients. Scand J Gastroenterol 1974; 9: 703-10.

${ }^{14}$ Knutson U, Olbe L, Ganguli PC. Gastric acid and plasma gastrin responses to sham-feeding in duodenal ulcer patients before and after resection of antrum and and duodenal bulb. Scand J Gastroenterol 1974; 9: 351-6.

${ }^{15}$ Konturek SJ, Kwiecién N, Obtulowicz W et al. Comparison of the cephalic phase of gastric secretion in healthy subjects and duodenal ulcer patients. Role of vagal innervation. Gut 1979; 20: 875-81.

${ }^{16}$ Richardson CT. Effect of $\mathrm{H}_{1}$-receptor antagonists on gastric acid secretion and serum gastrin concentration. Gastroenterology 1978; 74: 366-70.

${ }^{17}$ Konturek SJ, Tasler J, Obtulowicz W, Rehfeld JF. Effect of metiamide, a histamine $\mathrm{H}_{2}$-receptor antagonist, on mucosal blood flow and serum gastrin level. Gastroenterology 1974; 66: 982-6.

${ }^{18}$ Soll AH, Grossman MI. Cellular mechanisms in acid secretion. An Rev Med 1978; 29: 495-507.

${ }^{19}$ Delle Fave GF, Tamburrano G, De Magistris L, et al. Gynecomastia with cimetidine. Lancet 1977; 1: 1319 (letter).

${ }^{20}$ Carlson HE, Ippoliti AF. Cimetidine, an $\mathrm{H}_{2}$ antihistamine, stimulates prolactin secretion in man. J Clin Endocrin Met 1977; 45: 367-70.

${ }^{21}$ Van Thiel DH, Gavaler JS, Smith WI Jr, Paul G. Hypothalamic-pituitary-gonadal dysfunction in men using cimetidine. $N$ Engl J Med 1979; 300: 1012-5.

${ }^{22}$ McMillen MA, Ambis D, Siegel JH. Cimetidine and mental confusion. $N$ Engl $J$ Med 1978; 298: 284-5 (letter). 